HORTSCIENCE 27(1):75. 1992.

\title{
Early Season Leaf Removal Reduces Fruit Set and Size in Cranberry (Vaccinium macrocarpon Ait.)
}

\author{
T.R. Roper ${ }^{1}$, E.J. Stang ${ }^{2}$, and G.M. Hawker ${ }^{3}$ \\ Department of Horticulture, University of Wisconsin, Madison, WI 53706
}

Additional index words. photosynthate partitioning

Fruit set is a major limiting factor in cranberry production. Many more flowers are produced than fruit. Intraplant competition for resources has been implicated as a possible limitation to fruit set (Baumann and Eaton, 1986; Birrenkott and Stang, 1989, 1990).

Photosynthate for growth of individual fruit in cranberry may come from one or more sources, including carbohydrates stored in perennial tissues, photosynthesis by 1-yearold or newly formed leaves on the upright bearing the fruit, or from reserves or photosynthesis of adjacent connected uprights. This research was undertaken to determine the relative importance of newly formed leaves on cranberry fruit set and growth.

A 2-year-old bed of 'Crowley' cranberry growing near Babcock, Wis., was studied. At 2-week intervals, from 16 June to 21 Sept. 1982 , new vegetative growth (apical bud and leaves) was removed from 14 fruiting uprights. These uprights were examined periodically during the season and any regrowth was removed as needed. On 12 Oct. the uprights from the eight leaf removal dates were harvested along with 28 untreated control uprights. For each upright, the number of flowers and fruits was counted and percent fruit set calculated. The berries were removed from the uprights and the berry fresh weight and length were measured. Transformed data were tested by analysis of variance with mean separation by LSD following a significant $F$ value.

Early removal of the newly produced leaves resulted in a reduced fruit count and fruit set

Received for publication 3 Mar. 1991. Accepted for publication 15 Aug. 1991, The cost of publishing this paper was defrayed in part by the payment of page charges. Under postal regulations, this paper therefore must be hereby marked $a d$ vertisement solely to indicate this fact.

${ }^{1}$ Assistant Professor.

${ }^{2}$ Professor.

${ }^{3}$ Former Graduate Research Assistant.
(Table 1). The effect was most severe when leaves were removed on 14 July.

Fruit set on uprights from which leaves were removed in August or September was higher than that typically reported in the literature for undisturbed plants (25\% to $40 \%)$ in older beds (Birrenkott and Stang, 1989). The unusually high fruit set likely is related to the age of the planting. Upright density in a 2-year-old bed, as used by us, is normally substantially lower than in an older bed. Uprights thus were in full sun with little shading and competition.

Visible bud growth in cranberry occurs in mid to late May with flowering beginning in late June and continuing for 3 to 4 weeks, into July. Fruit set was reduced most when leaves were removed near the end of the blossoming period, when the earliest set and newly expanding fruit would likely have the greatest demand for photosynthate. Removing the lowest two flowers or fruit early in their development increased fruit set on upper flowers more than removing fruit late during their development (Birrenkott and Stang, 1990). In addition, total nonstructural carbohydrates are at their lowest levels of the season during the fruit set period (Hagidimitriou and Roper, 1991).

Leaf removal on 28 July or later had essentially no effect on fruit count or fruit set
(Table 1). This result suggests that, later in the season, leaves further away from the fruit became more important in supporting fruit growth. This phenomenon has also been shown for apple (Rom and Ferree, 1986).

Fruit size, measured as mean berry fresh weight and mean berry length, was reduced significantly when the newly formed leaves were removed on 30 June or 14 July (Table 1). However, when leaves were removed earlier (June 16) or later in the season (28 July or later), berry size was similar to that of the control.

Removing the apical bud and new leaves on individual cranberry uprights during the blossoming period reduced fruit set and fruit size. The effect was greatest at the end of flowering when fruit are growing most rapidly and the potential demand for photosynthate is highest. This work suggests that competition for photosynthate may be a major limiting factor for fruit set in cranberry. New leaves on uprights appear to be an important source of carbohydrates; as the season progresses, other photosynthate sources may contribute needed resources.

\section{Literature Cited}

Baumann, T.F. and G.W. Eaton. 1986. Competition among berries on the cranberry upright. J. Amer. Soc. Hort. Sci. 111:869-872.

Birrenkott, B.A. and E.J. Stang. 1989. Pollination and pollen tube growth in relation to cranberry fruit development. J. Amer. Soc. Hort. Sci. 114:733-737.

Birrenkott, B.A. and E.J. Stang. 1990. Selective flower removal increases cranberry fruit set. HortScience 25:1226-1228.

Hagidimitriou, M. and T.R. Roper. 1991. Seasonal changes in photosynthesis and nonstructural carbohydrates in fruiting vs. vegetative cranberry uprights. HortScience 26:164. (Abstr.)

Rom, C.R. and D.C. Ferree. 1986. The influence of fruiting and shading of spurs and shoots on spur performance. J. Amer. Soc. Hort. Sci. $111: 352-356$

Table 1. Effect of date of leaf removal on fruit count, fruit set, and fruit size of 'Crowley' cranberries in Wisconsin, 1982. ( $n=14)$

\begin{tabular}{lcccc}
\hline \hline Date, 1982 & $\begin{array}{c}\text { Fruit/upright } \\
\text { (no.) }\end{array}$ & $\begin{array}{c}\text { Fruit set } \\
(\%)\end{array}$ & $\begin{array}{c}\text { Mean fresh } \\
\text { berry wt } \\
(\mathrm{g})\end{array}$ & $\begin{array}{c}\text { Mean berry } \\
\text { length } \\
(\mathrm{mm})\end{array}$ \\
\hline 16 June & $1.3 \mathrm{~b}^{\mathrm{z}}$ & $26.4 \mathrm{a}$ & $1.4 \mathrm{~b}-\mathrm{d}$ & $14.0 \mathrm{c}$ \\
30 June & $1.4 \mathrm{~b}$ & $27.7 \mathrm{a}$ & $1.1 \mathrm{~b}$ & $12.8 \mathrm{ab}$ \\
14 July & $0.43 \mathrm{a}$ & $8.9 \mathrm{a}$ & $0.87 \mathrm{a}$ & $12.3 \mathrm{a}$ \\
28 July & $2.6 \mathrm{c}$ & $55.1 \mathrm{~b}$ & $1.2 \mathrm{bc}$ & $13.9 \mathrm{bc}$ \\
10 Aug. & $3.3 \mathrm{~cd}$ & $75.5 \mathrm{c}$ & $1.4 \mathrm{~cd}$ & $14.3 \mathrm{c}$ \\
25 Aug. & $2.8 \mathrm{~cd}$ & $54.5 \mathrm{~b}$ & $1.3 \mathrm{~b}-\mathrm{d}$ & $14.5 \mathrm{c}$ \\
7 Sept. & $2.4 \mathrm{~cd}$ & $56.8 \mathrm{~b}$ & $1.4 \mathrm{~cd}$ & $14.5 \mathrm{c}$ \\
21 Sept. & $3.6 \mathrm{~d}$ & $79.8 \mathrm{~d}$ & $1.6 \mathrm{~d}$ & $14.8 \mathrm{c}$ \\
Control & $3.3 \mathrm{~cd}$ & $66.1 \mathrm{bc}$ & $1.4 \mathrm{~b}-\mathrm{d}$ & $14.5 \mathrm{c}$ \\
\hline
\end{tabular}

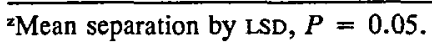

